\title{
Ripening for improving the quality of inoculated cheese Rhizopus oryzae
}

\author{
SOLIKAH ANA ESTIKOMAH ${ }^{1, \bullet}$, SUTARNO $^{2}$, ARTINI PANGASTUTI ${ }^{2}$ \\ ${ }^{1}$ Bioscience Program, School of Graduates, Sebelas Maret University, Surakarta 57126, Central Java, Indonesia \\ ${ }^{2}$ Department of Biology. Faculty of Mathematics and Natural Sciences, Sebelas Maret University, Surakarta 57126, Central Java, Indonesia
}

Manuscript received: 17 November 2009. Revision accepted: 26 January 2010.

\begin{abstract}
Estikomah SA, Sutarno, Pangastuti A 2010. Ripening for improving the quality of inoculated cheese Rhizopus oryzae. Nusantara Bioscience 2: 1-6. Cheese is dairy product resulted from fermented milk in which the fermentation process can be done by lactic acid bacteria or fungus. Rhizopus oryzae is able to produce lactic acid, protease, and lipase. The ripening process changes the taste and texture. The purpose of this study is ripening to improve the quality of inoculated cheese $R$. oryzae. In this research, the ripening was conducted the concentration variation of temperature $\left(5^{\circ} \mathrm{C}, 10^{\circ} \mathrm{C}, 15^{\circ} \mathrm{C}\right)$, and time $(7$ days, 14 days). The procedure of research consisted of two steps, namely un-ripened cheese preparation followed by ripening cheese preparation. Cheese produced in this study analyzed the value of $\mathrm{pH}$, fat content, protein content, amino acid levels and identification of microbe with ANOVA then followed by DMRT at 5\% level of significance. Data results were analyzed with the like's nonparametric statistical test, followed by Fridman Wilcoxon Signed Rank Test (WSRT) at 5\% level significance. The results showed that the preferred ripened cheese panelist was at a temperature of $15^{\circ} \mathrm{C}$ for 14 days. Ripening conditions affect $\mathrm{pH}$, fat content, protein content and do not affect the levels of amino acids that formed ripened cheese. The best quality ripened cheese, i.e. at a temperature of $15^{\circ} \mathrm{C}$ for 14 days, had a pH value of 4.40 , the highest protein content of $9.78 \%$, and fat content of $35.02 \%$. The results of identified microbe in un-ripened cheese and ripened cheese include Enterococcus hirae (Enterococcus faecalis), Bacillus subtilis, and Aspergillus sp.
\end{abstract}

Keywords: cheese, fermentation, Rhizopus oryzae, ripening, temperature.

\begin{abstract}
Abstrak. Estikomah SA, Sutarno, Pangastuti A. 2010. Pemeraman untuk meningkatkan kualitas keju yang diinokulasi Rhizopus oryzae. Nusantara Bioscience 2: 1-6. Keju merupakan makanan hasil fermentasi dari susu yang proses fermentasinya dilakukan oleh bakteri asam laktat maupun jamur. Rhizopus oryzae diketahui mampu menghasilkan asam laktat, protease, dan lipase. Perubahan cita rasa dan tekstur keju terjadi selama pemeraman keju. Tujuan penelitian ini adalah untuk meningkatkan kualitas keju yang diinokulasi $R$. oryzae melalui pemeraman. Pemeraman dilakukan dengan variasi waktu $\left(7,14\right.$ hari) dan suhu $\left(5^{\circ} \mathrm{C}, 10^{\circ} \mathrm{C}, 15^{\circ} \mathrm{C}\right)$. Penelitian ini terdiri dua tahap, yaitu pembuatan keju mentah diikuti pemeraman keju mentah tersebut. Keju penelitian dianalisis nilai pH, kadar lemak, kadar protein, kadar asam amino dan diidentifikasi mikrobanya. Data hasil penelitian dianalisis dengan uji sidik ragam (ANAVA), kemudian dilanjutkan dengan uji berjarak ganda Duncan (DMRT) pada taraf signifikansi 5\%. Data hasil tingkat kesukaan dianalisis dengan statistik nonparametrik uji Fridman yang dilanjutkan dengan Wilcoxon Signed Rank Test (WSRT) pada taraf sigifikansi 5\%. Hasil penelitian menunjukkan bahwa keju peram yang disukai panelis adalah keju peram pada suhu $15^{\circ} \mathrm{C}$ selama 14 hari. Kondisi pemeraman berpengaruh terhadap nilai $\mathrm{pH}$, kadar lemak, kadar protein dan tidak berpengaruh pada kadar asam amino. Kualitas keju peram terbaik terdapat pada kondisi suhu $15^{\circ} \mathrm{C}$ selama 14 hari, memiliki nilai $\mathrm{pH} 4,40$, kadar protein tertinggi yaitu sebesar 9,78\%, dan kadar lemak sebesar 35,02\%. Hasil identifikasi mikroba pada keju mentah dan keju peram meliputi Enterococcus hirae (Enterococcus faecalis), Bacillus subtilis, dan Aspergillus sp.
\end{abstract}

Kata kunci: keju, fermentasi, Rhizopus oryzae, pemeraman, suhu.

\section{INTRODUCTION}

Milk is a food that consists of various nutrients in balanced proportions. Its main constituent is water, protein, fat, lactose, minerals, and vitamins. Milk is yielded from livestock such as cattle, buffalo, and goats. Milk production from dairy farmers is distributed to the milk factories and processed by them into a liquid ready to drink milk. Milk produced by breeders can only be sold to a cooperative economic enterprise or factory and processed into a ready to drink milk. There are some basic problems bear down upon dairy farmers, they are low resistance on the milk or easily damaged, the bargaining position of farmers against low milk prices and lack of absorptive capacity of milk production by the manufacturer/cooperatives as well as poor knowledge of dairy farmers. On the other hand, breeders always wanted the milk that is produced can be used completely without any damage or wasted, so we need some milk processing which is aimed to preserve milk for much longer when stored. Cheese is a dairy product (Daulay 1991).

The fungus Rhizopus oryzae is able to produce lactic acid (Purwoko and Pamudyanti 2004). R. oryzae also has protease enzyme which has similar characteristics as rennet 
(Hadiwiyoto 1983). Lactic acid will help preserve the milk, while the protease functions to wad milk casein. Besides lactic acid and protease, $R$. oryzae is capable to produce lipase that functions as a solver of fat that will enhance the taste of cheese.

In manufacturing of cheese, ripening is one of the important stages. Cheese product which has a ripening can change a young cheese slowly into a mature cheese. The ripening process changes the taste and texture. The changes are caused by protein breakdown into simpler peptides and amino acids, fats into fatty acid solution and volatile acids such as acetic and propionic acid, lactose fermentation, citrate, and other organic materials into acids, esters, alcohol, taste, and diacetyl other components.

The process of making a ripened cheese involves acidification and ripening. Acidification of milk is done by adding acid or inoculation of microbes. Direct acidification of milk by adding acid is less suitable for ripened cheese making process because during the ripening process there is no real change of proteins (proteolysis), fat (lipolysis), and lactose, whereas acidification using inoculums can cause biochemical changes, including proteolysis, lipolysis and lactose fermentation. Biochemical changes can affect flavor and texture (Septiana 1994).

Ripening of cheese is done by storing the cheese for some time and at a certain temperature. The longer the ripening, the stronger the flavor of cheese is formed. In cheese ripening, maturing temperature affects the speed of proteolytic activity and acid production. High temperatures will accelerate the process, but not profitable. At high temperatures, acid production is quicker, causing a strong sour taste and accelerating evaporation so that more water loss and decay more quickly. At low temperatures, a proper balance of acid production and proteolytic activity occur, and water evaporation is inhibited (Daulay 1991).

This research is about the cheese which was inoculated by $R$. oryzae by using variations of temperature and time of ripening. Cheeses are brooded in this study analyzed the value of $\mathrm{pH}$, fat content, protein and amino acid contents, microbial identification and preference test.

\section{MATERIALS AND METHODS}

\section{Materials research}

The main material used is cow's milk from dairy cows in Boyolali District, Central Java, and Rhizopus oryzae propagated by the Faculty of Agriculture Sebelas Maret University, Surakarta.

\section{Procedures}

\section{Preparation of culture media}

Media manufacturing process begins with mixing the ingredients PDA (Potato Dextrose Agar), which is a medium for the growth of $R$. oryzae. Distilled water is then inserted into the Erlenmeyer flask, then heated on hot plate and homogenized with a magnetic stirrer. Once the mixture boils, PDA media was poured into a test tube and proceed with the process of sterilization using the autoclave at a temperature $121^{\circ} \mathrm{C}$ at 1 atm pressure for 30 minutes, then test tube placed in a tilted position in order to form slanted media.

The working culture of $R$. oryzae is ready to be used for the manufacture of starter. Work culture is obtained with culture rejuvenate $R$. oryzae by inoculating a pure culture into the PDA side, then incubating at 37TAC for 3-4 days, while the rest is stored at a temperature 4TAC as a stock culture and rejuvenated every 6 months (Wijaya 2002; Suharyanto et al. 2006). Starter made by inoculating 250 $\mathrm{mL}$ fresh milk (skim milk liquid) with $R$. oryzae from PDA at the age of 3-4 days, propagation of $R$. oryzae taken as many as 50 cells $/ \mathrm{mL}$ ( 3 ose) and incubated at $37^{\circ} \mathrm{C}$ for one day (Nurhidayati 2003).

\section{Making cheese}

Fresh cow's milk, as much as $3600 \mathrm{~mL}$ pasteurized up to $70^{\circ} \mathrm{C}$ for 30 seconds. Once pasteurized, the milk was cooled until the temperature reaches $37^{\circ} \mathrm{C}$ and then inserted into the 8 piece glass beaker with a volume of $200 \mathrm{~mL}$. Bottles filled with milk that has been inoculated are then incubated in an incubator at a $37^{\circ} \mathrm{C}$ for 9 hours. During the incubation, bottles were covered with aluminum foil. The part that was clotted called curd while the liquid is called whey (Wardhani 1996). After that the milk was heated for 30 minutes at a $40^{\circ} \mathrm{C}$, then cooled for 1 hour, stirred every 5 minutes (Hadiwiyoto 1983), and then filtered with clean gauze. Filtering is done to separate curd and whey. Formed curd is taken while the whey is removed (Legowo et al. 2003). Curd wrapped in clean gauze continued pressing to give compactness and shape of the cheese, and remove the remains of whole whey (Hadiwiyoto 1983). Formed curd was salted as much as $4 \%$. Salt is sprinkled in the form of fine crystal, then stir until completely blended. The salted curd is then wrapped with aluminum foil and matured for 0 day (without ripening), 7 days, and 14 days, with temperature of curing $5^{\circ} \mathrm{C}, 10^{\circ} \mathrm{C}$, and $15^{\circ} \mathrm{C}$.

\section{Microbiological test}

Microbiological test involved the calculation of total microbes and microbial identification. Calculation of total microbial cheese made by weighing $25 \mathrm{~g}$ and then homogenized with $225 \mathrm{~mL}$ of distilled water (Ceylan et al. 2003; Rosa et al. 2003; Mennane et al. 2007). Calculation of total microorganisms was done on the basis of the Standard Plate Count. Fertilization is done with medium Plate Count Agar (PCA) by dropping $1 \mathrm{~mL}$ of inoculation into sterile Petri PCA, and the subsequent media that has been cold poured into sterile Petri saucer as much as 12-15 $\mathrm{mL}$, the mixture is homogenized with a Petri saucer by moving it to form a figure eight direction. Having to harden, Petri saucer was incubated upside down at $37^{\circ} \mathrm{C}$ for 24-48 hours. Then the colonies formed are counted. Identification was done by isolating colonies of microbes then growing it on PDA media for mold and on MRSA media for bacteria. Identification of mold was based on its morphologic characteristics. Identification of bacteria was using the BD Phoenix TM. 


\section{Lipid analysis}

Soxhlet fat analysis method is as follows: Samples of 3 $\mathrm{g}$ was taken and then inserted into the timber. Put the flask which has already been cleaned into the oven, then add the boiling stone and weighed as empty weight. Timbel is inserted into the soxhlet, then connected with soxhlet fat flask, and then add a liquid fat solvent of $150 \mathrm{~mL}$ of ether through the soxhlet. Flask fat and soxhlet are connected with bath extracted for 6 hours. After the extract is complete, flask fat is evaporated to remove solvent. Flask fat is put into the oven at $105^{\circ} \mathrm{C}$ for 1 hour. After it is cold, it is weighed as final weight (weight and fat flask). The sample calculation formula is:

$$
\begin{aligned}
& \text { Lipid content }=\frac{\mathrm{c}-\mathrm{b}}{\mathrm{a}} \times 100 \% \\
& \mathrm{a}=\text { Weight of sample } \\
& \mathrm{b}=\text { Weight of fat and boiling flask } \\
& \mathrm{c}=\text { Weight of fat flasks, stone boiling and fat }
\end{aligned}
$$

\section{Protein content}

Protein content is analyzed by Lowry-Folin method by spectrophotometer (Sudarmadji et al. 1984). Measurement begins with the manufacture of standard solution of BSA (Bovine Serum Albumin). Dilution series was made from standard solutions with respective concentrations of 0.00 , $0.06,0.18,0.24$, and $0,30\left(\mathrm{mg} / \mathrm{mL} \mathrm{H}_{2} \mathrm{O}\right)$ and inserted into each test tube. $1 \mathrm{ml}$ solution $\mathrm{D}$ is added into the test tube and then is whirled for 5 minutes. After that, the addition of reagents $\mathrm{E}$ of $3 \mathrm{~mL}$ and then allowed to stand for 10 minutes. OD measurements performed at a wavelength of $560 \mathrm{~nm}$ using spectrophotometer. The next steps were taking $1 \mathrm{~g}$ of cheese sample and dissolve it in $100 \mathrm{~mL}$ of distilled water and then stirring with a magnetic stirrer, the solution was filtered and added $100 \mathrm{~mL}$ of distilled water. 1 $\mathrm{mL}$ sample solution was taken and then inserted into a test tube and then added by $1 \mathrm{~mL}$ of Lowry reagent $\mathrm{D}$, whirled with vortex for 5 minutes. Next reagent Lowry $\mathrm{E}$ as much as $3 \mathrm{~mL}$ added into test tubes and whirled with vortex and then incubated at room temperature for 45 minutes. OD measurement at a wavelength of $590 \mathrm{~nm}$ was using a spectrophotometer. Sample calculation formula is:

$$
\begin{aligned}
& \% \text { protein }=\frac{\operatorname{axb}}{\mathrm{c}} \times 100 \% \\
& \mathrm{a}=\text { concentration } \\
& \mathrm{b}=\text { dilution factor } \\
& \mathrm{c}=\text { a lot of sample }(\mathrm{g})
\end{aligned}
$$

\section{Amino acid content of cheese}

Amino acid content of cheese was analyzed by HPLC (High-Performance Liquid Chromatography). Cheese samples in which amino acid content will be analyzed was prepared in advance, by taking $5 \mathrm{~g}$ of cheese samples that have been ground smoothly into the Erlenmeyer covered with grindstones, homogenized using a magnetic stirrer and hydrolyzed at a temperature of $110^{\circ} \mathrm{C}$ for 12 hours, filtered using Whatman filter paper 41 , and the $\mathrm{pH}$ was adjusted to normal ( $\mathrm{pH} \mathrm{7).} 100 \mathrm{ml}$ of distilled water is added, take $3 \mathrm{~mL}$ of that solution and filter with millex $0.45 \mu \mathrm{m}$. For injection into the HPLC, take $10 \mu \mathrm{l}$ of milex solution $+990 \mathrm{~mL}$ of OPA and whirled in a vortex. Put it into reaction for 3 minutes, and then inject it into the HPLC.

Preparation of standard solution. Standard stock consists of L-threonin $=1050 \mathrm{ppm} ; \mathrm{L}$-methionine $=1000$ ppm; L-valine $=1010$ ppm; L-thriptophan $=1010, \mathrm{~L}$ Phenilalanine $=1000 \mathrm{ppm} ; \mathrm{L}$-isoleusine $=1060$, L-Leucine $=1010 \mathrm{ppm} ;$ L-lycine $=1000 \mathrm{ppm}$, each drawn by comparison 1:1:1:1:1:1:1:1 into $10 \mathrm{~mL}+990 \mathrm{~mL}$ OPA diijeksi to HPLC. Amino acid cheese detected by HPLC with a set of HPLC equipment. The prepared sample was taken as much as $20 \mathrm{~mL}$ using the injector. Amino acids was detected by a set of tools Eurospher 100-5 C18 HPLC column, 250x4.5 mm with pre-column $\mathrm{P} / \mathrm{N}$ : $1115 \mathrm{Y} 535$. Eluent: $\mathrm{A}=0: 01 \mathrm{M}$ acetate buffer $\mathrm{pH} 5.9, \mathrm{~B}=(\mathrm{MeOH}$ : 0:01 $\mathrm{M}$ acetate buffer $\mathrm{pH}$ 5.9).

\section{Organoleptic test}

Organoleptic test which is conducted is a test of preference. This preference test assesses the level of color, flavor, aroma, and texture of cheese. The assessment was conducted by 20 untrained panelists. This test refers to Zulaekah and Widiyaningsih (2005). A five-level scale was stated (level 1-5), start from 1 (strongly dislike), 2 (not like), 3 (somewhat like), 4 (like), and 5 (very like).

\section{Data analysis}

Data obtained from analysis which consists of the $\mathrm{pH}$ value, fat content, and protein content and total microbial was analyzed by analysis of variance (Anova) to determine whether there is any treatment effect followed by a test of Duncan's Multiple Range Test (DMRT) at the significance level of $5 \%$ to know the real difference among the treatments. Data favorite level test results were analyzed descriptively with Friedman nonparametric statistical tests (Friedman test) followed by Wilcoxon Signed Rank Test (WSRT) at 5\% significance level.

\section{RESULTS AND DISCUSSION}

\section{The degree of acidity ( $\mathrm{pH})$}

The $\mathrm{pH}$ is a measure of the value of dissociated hydrogen ions in solution, thus aiming to find out the $\mathrm{pH}$ measurements of cheese acidity caused by the presence of hydrogen ions. PH value of ripened cheese which was inoculated with $R$. oryzae can be seen in Table 1 . According to De Souza et al. (2003), pH levels decreased during the ripening process. Decrease in $\mathrm{pH}$ of cheese is influenced by the amount of lactic acid produced by microorganisms, the higher the lactic acid then the $\mathrm{pH}$ was lower. The decrease in $\mathrm{pH}$ value is caused by the activity of bacteria in this cheese. BAL is in the cheese (Bacillus subtilis and Enterococcus hirae) are able to produce lactic acid from sugar that will be needed in forming taste, preventing the growth of pathogenic bacteria, and the 
safety of the final product (Kayagil 2006). Lactic acid is the result of glucose metabolism. Increased lactic acid is characterized by a decrease in $\mathrm{pH}$. Increased lactic acid caused by $\mathrm{H}+$ ions that occur because of decomposition of lactose produces acids that are easily evaporated, and the outbreak of organic phosphate contained in casein, resulting in acid (Mc Kay et al. 1971).

Table 1. The $\mathrm{pH}$, fat content (\%), protein content (\%), ripened cheese inoculated with $R$. oryzae

\begin{tabular}{|c|c|c|c|}
\hline \multirow{2}{*}{ Ripening period } & \multicolumn{3}{|c|}{ Temperature } \\
\hline & $5^{\circ} \mathrm{C}$ & $10^{\circ} \mathrm{C}$ & $15^{\circ} \mathrm{C}$ \\
\hline \multicolumn{4}{|l|}{ pH } \\
\hline 7 days & $5,44^{b c}$ & $5,09^{\mathrm{b}}$ & $4,87^{a b}$ \\
\hline 14 days & $5,14^{\mathrm{bc}}$ & 4,88 ab & $4,40^{a}$ \\
\hline \multicolumn{4}{|l|}{ Fat content $(\%)$} \\
\hline 7 days & $34,56^{\mathrm{ab}}$ & $34,48^{\mathrm{ab}}$ & $35,30^{\mathrm{ab}}$ \\
\hline 14 days & $32,43^{\mathrm{a}}$ & $33,31^{\mathrm{ab}}$ & $35,02^{\mathrm{ab}}$ \\
\hline \multicolumn{4}{|l|}{ Protein content (\%) } \\
\hline 7 days & $6.28^{\mathrm{d}}$ & $7.56^{\mathrm{c}}$ & $8,34^{\mathrm{b}}$ \\
\hline 14 days & $7.22^{\mathrm{c}}$ & $7.60^{c}$ & $9,78^{\mathrm{a}}$ \\
\hline
\end{tabular}

Note: Figures with different letters in the same column indicate significant differences $(\mathrm{P}<0.05)$ in Duncan's multiple range test.

\section{Lipid content}

Fats are a source of some components giving flavor, aroma, and texture of cheese. Fusion of fat in the cheese occurs due to trapped fat globules at the time of the protein wadding progress (Daulay 1991). Data results of calculating the value of fat content in cheese inoculated with $R$. oryzae can be seen in Table 1 . The results of this study indicate that the lipid content will be decreased in a longer ripening process. The results are consistent with the results of research conducted by Kayagil (2006) decreasing levels of fat in the cheese due to the ripening process occurs because of the degradation of fat with the help of lipase. In the process of fat degradation, fatty acid is formed. There are volatile fatty acids and non-volatile fatty acid. According to Prawisuma (2007) during the ripening process, fat is hydrolyzed into various volatile fatty acids. Volatile fatty acids are fatty acids which are easily evaporated. These easily evaporated fatty acids cause levels of fat in cheese reduced. Reduced levels of fat besides caused by the formation of volatile acid, it is also caused by using of some fats as a source of energy in metabolism activity. Fat is used as an energy source through the renovation process initiated by the hydrolysis of triglycerides into glycerol and fatty acids with the assistance of lipase.

\section{Protein content}

Proteins in milk are composed by whey and casein, whereas the remaining proteins in the cheese are casein because the formed whey has been released in the process of cheese formation (Murwaningsih 2003). The value protein content in ripened cheese inoculated with $R$. oryzae by the treatment of ripening duration and temperature variations can be seen in Table 1 . High protein levels of ripened cheese at a temperature of $15^{\circ} \mathrm{C}$ for 14 days are in accordance with the results of research by Licitra et al. (2000) which showed an increase in protein content during ripening of 0 to 12 months. At 0 months of ripening protein content is $25.30 \%$ and then increased at $29.24 \%$ after 12 months of ripening. Compared with controls that have a protein content of $2.23 \%$, the ripened cheese in this study had higher protein content. Increased levels of protein in cheese is due to the opportunity given for microbes ( $E$. hirae, Bacillus subtilis, Aspergillus sp.), and the enzymes in the cheese curd to hydrolyze proteins during the ripening process. Protein breakdown during ripening will result in a high protein, more flexible and soft cheese structure, and aromatic taste, because the rigid proteins and insoluble nitrogen are converted into soluble form (Daulay 1991).

\section{Essential amino acid content of ripened cheese}

Amino acids are homologous series of compounds containing two functional groups, i.e. amino groups and carboxylate groups which are attached to the same carbon atom. Essential amino acid analysis results that were inoculated with starter $R$. oryzae can be seen in Table 2 . During the ripening process, the highest levels of amino acids are in the treatment of 7 days. High level of amino acid in the 7-days treatment of ripened cheese is caused by proteolysis occurs on the cheese. Meanwhile, on 14-day treatment of ripened cheese, the content of amino acid decline due to the occurrence of amino acid catabolism. Amino acids are precursors to the various flavor components in cheese (Urbach 1997; Engels et al. 1997). Catabolism of amino acids produces a number of aroma components found in the cheese. Mechanism of amino acid catabolism includes oxidation deamination, decarboxylation, transaminase, and reduction reactions that would form the aldehyde, alcohol, indole, acid, phenolic and sulfur (Hansen et al. 2001; Williams et al. 2001).

Table 2. Amino acid levels in cheese inoculated with $R$. oryzae.

\begin{tabular}{lccc}
\hline \multicolumn{1}{c}{$\begin{array}{c}\text { Essential amino acid } \\
\text { compound }\end{array}$} & \multicolumn{2}{c}{$\begin{array}{c}\text { Essential amino } \\
\text { acid contents (\%) }\end{array}$} & $\begin{array}{c}\text { Ripened } \\
\text { cheese }\end{array}$ \\
\cline { 2 - 4 } 0 day & $\mathbf{7 ~ d a y}$ & $\mathbf{1 4}$ day \\
\hline L-Threonine & 1.15 & 1.68 & 1.58 \\
L-Methionine & 0.47 & 0.62 & 0.58 \\
L-Valine + L-Tryptophan & 0.70 & 1.78 & 1.65 \\
L-Phenylalanine & 0.66 & 1.12 & 1.00 \\
L-Isoleucine & 0.48 & 0.99 & 0.84 \\
L-Leucine & 1.28 & 2.30 & 1.96 \\
L-Lycine & 1.64 & 2.42 & 2.44 \\
Total & 6.38 & 10.91 & 10.05 \\
\hline
\end{tabular}

\section{Test of cheese preferences}

This test is conducted to know consumer preference level of cheese produced include predilection of texture, flavor, color, and flavor. The results of statistical analysis are shown in Table 3. From Table 3, it is known that the taste of ripened cheese on $15^{\circ} \mathrm{C}$ for 14 days has the most 
preferred taste over the other. Cheese in the ripening process of $5^{\circ} \mathrm{C}$ for 7 days has a taste of the least preferred.

Table 3. Test scores upon predilection of flavor, aroma, color, and texture in ripened cheese.

\begin{tabular}{lcccc}
\hline Ripening duration & Flavor & Aroma & Color & Texture \\
\hline $5^{\circ} \mathrm{C}$ during 7 days & $3.40^{\mathrm{a}}$ & $3.47^{\mathrm{a}}$ & $4.70^{\mathrm{a}}$ & $4.25^{\mathrm{a}}$ \\
$5^{\circ} \mathrm{C}$ during 14 days & $3.75^{\mathrm{a}}$ & $4.43^{\mathrm{a}}$ & $3.40^{\mathrm{a}}$ & $3.75^{\mathrm{a}}$ \\
$10^{\circ} \mathrm{C}$ during 7 days & $4.45^{\mathrm{a}}$ & $3.95^{\mathrm{a}}$ & $4.22^{\mathrm{a}}$ & $4.60^{\mathrm{a}}$ \\
$10^{\circ} \mathrm{C}$ during 14 days & $4.03^{\mathrm{a}}$ & $4.45^{\mathrm{a}}$ & $4.00^{\mathrm{a}}$ & $4.13^{\mathrm{a}}$ \\
$15^{\circ} \mathrm{C}$ during 7 days & $4.22^{\mathrm{a}}$ & $3.83^{\mathrm{a}}$ & $3.85^{\mathrm{a}}$ & $3.17^{\mathrm{a}}$ \\
$15^{\circ} \mathrm{C}$ during 14 days & $4.50^{\mathrm{a}}$ & $4.42^{\mathrm{a}}$ & $3.45^{\mathrm{a}}$ & $4.20^{\mathrm{a}}$ \\
Controls & $3.92^{\mathrm{a}}$ & $3.65^{\mathrm{a}}$ & $4.38^{\mathrm{a}}$ & $3.90^{\mathrm{a}}$ \\
\hline
\end{tabular}

Note: The larger the value, then the ripened cheese is increasingly preferred. Same superscript indicates no significant difference in Fridman test $5 \% .1$ = extremely dislike, $2=$ dislike, $3=$ somewhat like; 4 = like, 5 = very like it.

The aroma of cheese appears mainly due to the volatile formed during ripening. Results of non-parametric analysis show the most preferred aroma on ripening of $10^{\circ} \mathrm{C}$ for 14 days, while the least preferred flavor is in $5^{\circ} \mathrm{C}$ for 7 days which is ripened at the lowest temperatures, according to Daulay (1991) Low temperature inhibits the biochemical processes that lead to process inhibited the formation of aroma. When compared with control ripened cheese preferably, in this study the control used is the cheese without ripening (unripened), which is a type of fresh cheese where the aroma has not been formed and is still dominated by the aroma of milk (Murwaningsih 2003).

A non-parametric analysis result indicates a preferred color in ripened cheese $5^{\circ} \mathrm{C}$ for 7 days because this cheese has a more yellow color than others. According to Buckle (1987), cheese made from cow's milk without the dye will produce a yellow-white cheese. The color of cheese is influenced by fat content in cheese. Fat in cheese obtained with the help of the enzyme lipase, which can hydrolyze triglycerides into glycerol and fatty acids. The yellow color comes from carotene pigments which are fat soluble, so that more levels of fat in the cheese, the cheese color becomes more yellow, because of the more soluble pigment carotene. Non-parametric analysis results show that the assessment score is given by panelists on the texture of the most preferred, namely $10^{\circ} \mathrm{C}$ treatment for 7 days while the texture was the least preferred on $15^{\circ} \mathrm{C}$ treatment for 7 days.

\section{Microbiology identification}

Results of identification of microorganisms found in the control cheese (without ripening cheese), ripened cheese for 7 days, and ripened cheese for 14 days are shown in Table 4. In the control, 7 days ripening time and 14 days ripening time, there are 3 types of microbes which are the same, namely E. hirae, B. subtilis, Aspergillus sp. The number of molds progressively increased, while the number of bacteria becomes more and more declined (Table 4). This is because B. subtilis and E. hirae are thermoduric bacteria that have optimal temperature at 30$45^{\circ} \mathrm{C}$ while Aspergillus grows at an optimal temperature at $29-32^{\circ} \mathrm{C}$ so that ripening treatment at a temperature of $15^{\circ} \mathrm{C}$ causes Aspergillus is more able to survive than in $B$. subtilis and E. hirae.

Table 4. Microorganisms found during the ripening time of 7 and 14 days at $15^{\circ} \mathrm{C}$ on MRSA and PDA media.

\begin{tabular}{|c|c|c|c|}
\hline $\begin{array}{l}\text { Type of } \\
\text { media } \\
\text { (cfu/mL) }\end{array}$ & Control & 7 days & 14 days \\
\hline PDA & $\begin{array}{l}\text { Aspergillus sp. } \\
\left(1.2 \times 10^{4}\right)\end{array}$ & $\begin{array}{l}\text { Aspergillus sp. } \\
\left(1.1 \times 10^{4}\right)\end{array}$ & $\begin{array}{l}\text { Aspergillus sp. } \\
\left(2.8 \times 10^{4}\right)\end{array}$ \\
\hline MRSA & $\begin{array}{l}\text { E. hirae and } B \text {. } \\
\text { subtilis } \\
\left(3.8 \times 10^{4}\right)\end{array}$ & $\begin{array}{l}\text { E. hirae and } B \text {. } \\
\text { subtilis } \\
\left(3.3 \times 10^{4}\right)\end{array}$ & $\begin{array}{l}\text { E. hirae and } B \text {. } \\
\text { subtilis } \\
\left(3.2 \times 10^{4}\right)\end{array}$ \\
\hline
\end{tabular}

\section{The total number of microbial colonies of ripened cheese inoculated with $R$. oryzae}

The calculation of the total number of microbes in this study was conducted using SPC (Standard Plate Count) on PCA medium (Plate Count Agar) performed by dilution. The total numbers of microbes that participate in cheese ripening are shown in Table 5. The longer ripening time caused the number of microorganisms that grow less (Table 5). According to Amos (2007) microbes in cheese will grow rapidly in milk and curd during cheese making, then declines during ripening, due to a decline in $\mathrm{pH}$ during ripening, reduced lactose and high salt concentration.

Table 5. The number of microbes (x 104) on media Total Plate Count (TPC)

\begin{tabular}{lccc}
\hline \multirow{2}{*}{ Ripening time } & \multicolumn{3}{c}{ Temperature } \\
\cline { 2 - 4 } & $\mathbf{5}^{\circ} \mathbf{C}$ & $\mathbf{1 0}^{\circ} \mathbf{C}$ & $\mathbf{1 5}^{\circ} \mathbf{C}$ \\
\hline \multirow{2}{*}{7 days } & $10,99 \times 10^{4}$ ab & $11,95 \times 10^{4}$ ab & $12,99 \times 10^{4 b}$ \\
14 days & $10,12 \times 10^{4}$ a & $11,14 \times 10^{4}$ ab & $11,30 \times 10^{4 a b}$
\end{tabular}

Note: Figures with different letters in the same column indicate significant differences $(\mathrm{P}<0.05)$ in Duncan's multiple range test.

The $\mathrm{pH}$ value of cheese in this study is ranged from 4 to 5.44 (Table 1). From Table 1, it is noted that the longer ripening time led to a lower $\mathrm{pH}$ value. Low acidity levels causing microbes within the cheese die due to not acid resistant (Daulay 1991). Compared with controls, which is without ripening cheese that has a large number of microbes, ripened cheese has a little amount of microbes, caused by the $\mathrm{pH}$ in the ripened cheese is lower (4 to 5.44) than the $\mathrm{pH}$ of unripened cheese (5.5) which resulted in microbes in the cheese die due to not acid resistant.

\section{CONCLUSIONS AND SUGGESTIONS}

The use of long ripening variation affects the amount of microbes, $\mathrm{pH}$ value, fat content and protein content. The quality of the best cheese at a temperature of $15^{\circ} \mathrm{C}$ at 14 days ripening time, has a $\mathrm{pH}$ value of 4.40 , the highest protein content of $9.78 \%$, fat content of $35.02 \%$ and produces a sense of well-liked by the panelists. 
Identification of Bacillus subtilis using BD PhoenixTM has only $90 \%$ confidence level so it is expected that the next study will use molecular analysis to get more exact results. Further research is expected to have more additional secondary starter of ripened cheese making. Further research is expected to use the ripening temperature of $15^{\circ} \mathrm{C}$ with a time between 7 to 14 days.

\section{REFERENCES}

Amos LM. 2007. Enzymes from yeast adjuncts in proteolysis during Cheddar cheese ripening. [Dissertation]. University of the Free State, Bloemfontein, South Africa.

Buckle KA. 1987. Food science. UI Press, Jakarta. [Indonesian]

Ceylan Z, Turgoklu H, Dayisoylu KS. 2003. The microbiological and chemical quality of sikma cheese produced in Turkey. Pakistan J Nutr 2 (2): 95-97.

Daulay D. 1991. Fermentation of cheese. Bogor Agricultural University, Bogor. [Indonesian]

De Souza CFV, Rosa TD, Ayub MAZ. 2003. Change in the microbiological and physicochemical of Serrano cheese during manufacture and ripening. Braz J Microbiol 34(3): 260-266.

Engels WJM, Dekker R, de Jong C, Visser S. 1997. A comparative study of volatile compounds in the water-soluble fraction of various types of ripened cheese. Intl Dairy J 7: 255-263.

Hadiwiyoto S. 1983. Dairy products, fish, meat, and eggs. Liberty, Yogyakarta. [Indonesian]

Hansen TK, Tempel TVD, Cantor MD, Jacobsen M. 2001 Saccharomyces cerevisiae as starter culture in Mycella. Int J Food Microbiol 69: 101-111.

Kayagil F. 2006. Effect of traditional starter cultures on quality of cheese. [Thesis]. Department of Biotechnology, Middle East Technical University, Ankara.

Legowo A, Nurwantoro, Albaari AN. 2003. Levels of protein, fat, $\mathrm{pH}$ value and hedonic quality of cottage cheese with raw material of goat milk and skim milk. National Seminar on Animal Husbandry and Veterinary Technology. RD Center for Animal Husbandry, Bogor, 29-30 September 2003. [Indonesian]

Licitra G, Campo P, Manenti M, Portelli G, Scuderi S, Carpino S Barbano DM. 2000. Composition of Ragusano cheese during aging. J Dairy Sci 83(3): 404-411.
Mc Kay LL, Sandine WE, Elliker PR. 1971. Lactose utilization by lactic acid and bacteria. J Dairy Sci 37: 493.

Murwaningsih J. 2003. Chemical quality of Frisian Holstein (FH) dairy cows and cottage cheese produced in different genotypes of kappa casein. [S1 Thesis]. Bogor Agricultural University, Bogor. [Indonesian]

Nurhidayati T. 2003. Effect of papain enzyme concentration and temperature of fermentation on the quality of Cottage cheese. Kappa 4 (1): 13-17.

Prawisuma A. 2007. Profile of short-chain fatty acids, total solid material, and the smell of cheese from goat's milk with different ripening time. [S1 Thesis]. Bogor Agricultural University, Bogor [Indonesian]

Purwoko T, Pramudyanti IR. 2004. Effect of $\mathrm{CaCO}_{3}$ on the fermentation of lactic acid by Rhizopus oryzae. J Mikrobiol Indon 9: 19-22. [Indonesian]

Rosa DS, Filho RP, Chui QSH, Calil MR, Guedes CGF. 2003. The biodegradation of poly-b-(hydroxybutyrate), poly-(bhydroxybutyrate-co-b-valerate) and poly( $\varepsilon$-caprolactone) in compost derived from municipal solid waste. Eur Polym J 39: 233-237.

Septiana AT. 1994. Study of the inoculated cheese ripening Lactobacillus bulgaris and Streptococcus thermophilus. [Thesis]. Gadjah Mada University, Yogyakarta. [Indonesian]

Sudarmadji S, Haryono, B Suhadi. 1984. Analysis of food and agriculture. 2 nd ed. Penerbit Alumni, Bandung. [Indonesian]

Suharyanto, Tripanji, Abdullah MI, Syamsu K. 2006. CPO bioconversion with immobilized desaturase semipilot continuous systems on the scale for the production of oil containing GLA. Biotechnology Research Institute for Estate Crops of Indonesia. Bogor. [Indonesian]

Urbach G. 1997. The flavour of milk and dairy product. II. cheese: contribution of volatile compound. Intl J Dairy Technol 50:79-89.

Wardhani B. 1996. Studying the use of some types of rennet in the manufacture of Cottage cheese. [S1 Thesis]. Bogor Agricultural University, Bogor. [Indonesian]

Wijaya S. 2002. Isolation of chitinase from Scleroderma columnare and Trichoderma harzianum. J Ilmu Dasar 3 (1): 30-35. [Indonesian]

Williams AG, Noble J, Banks JM. 2001. Catabolism of amino acids by lactic acid bacteria isolated from cheddar cheese. Intl Dairy J 11:203215.

Zulaekah S, Widiyaningsih EN. 2005. Effect of tea leaf extract concentration on the manufacture of hard-boiled eggs to the number of bacteria and the receipt. Penelitian Sains \& Teknologi 6 (1): 1-13. [Indonesian] 